\section{PELATIHAN KEWIRAUSAHAAN DENGAN MEMBUAT BUKET SNACK SEBAGAI ALTERNATIF BUAH TANGAN BAGI SANTRI MIFTAHUL HUDA AL HUSNA KECAMATAN BUNGURSARI KOTA TASIKMALAYA}

\section{Tine Badriatin', Dina Agustina², R. Lucky Radi Rinandiyana ${ }^{3}$}

Program Studi Keuangan dan Perbankan Fakultas Ekonomi Universitas Siliwangi ${ }^{1}$,

Prodi Agribisnis Fakultas Pertanian Universitas Siliwangi ${ }^{2}$

Prodi Manajemen Fakultas Ekonomi Universitas Siliwangi ${ }^{3}$

${ }^{*}$ Corresponding author

Email : tinebadriatin@gmail.com

\begin{abstract}
Abstraksi
Pengabdian pada masyarakat yang dilaksanakan pada para santri Miftahul Huda Alhusna merupakan salah satu pelatihan kewirausahaan membuat buket snack sebagai salah satu alternative buah tangan dimana nantinya dengan inovasi pembuatan buket snack ini dapat mengembangkan jiwa kewirausahaan para santri. Kegiatan ini diikuti oleh 12 orang santri Miftahul Huda Alhusna Kecamatan Bungursari Kota Tasikmalaya selama kurang lebih 6 jam dimana kegiatan awal berupa seminar kewirausahaan dari dosen kewirausahaan dan pemasaran Fakultas Ekonomi Universitas Siliwangi kemudian praktek dan pelatihan pembuatan buket snack dengan memanfaatkan limbah kertas sebagai bahan penyangga buket agar lebih ekonomis. Hasil akhir kegiatan ini para santri mahir dan dapat berkresai sendiri mengembangkan bakat dan keterampilan dalam pembuatan buket snack sehingga bisa menjadi nilai jual yang tinggi dan menciptakan inovasi baru sehingga konsumen tidak merasa bosan dengan buket yang itu-itu saja.

Kata Kunci : Bank sampah, anggota, pengolahan data tabungan
\end{abstract}

\section{Abstract}

Community service carried out by Miftahul Huda Alhusna santri is one of entrepreneurship training in making snack bouquets as an alternative souvenir where later with the innovation of making snack bouquets can develop the entrepreneurial spirit of the students. This activity was attended by 12 students of Miftahul Huda Alhusna, Bungursari Subdistrict, Tasikmalaya City for approximately 6 hours where the initial activity was in the form of an entrepreneurial seminar from the entrepreneurship and marketing lecturer at the Faculty of Economics, Siliwangi University, then the practice and training of making snack bouquets by utilizing waste paper as a bouquet buffer material so that more economical. The end result of this activity is that the students are proficient and can work themselves to develop their talents and skills in making snack bouquets so that they can be of high selling value and create new innovations so that consumers do not feel bored with the same bouquet.

Keywords: Waste bank, members, savings data processin 


\section{PENDAHULUAN}

Memberi hadiah atau buah tangan dikalangan kawula muda dengan buket bunga sudah menjadi hal yang biasa, sayangnya buket bunga yang kita berikan sering layu dan menjadi sampah. Salah satu alternative pengganti buah tangan atau hadiah buket bunga yaitu dengan buket snack. Pemberian dengan buket snack selain harganya murah dan terjangkau juga lebih dapat memberikan manfaat karena isinya dapat kita makan. Tren pemberian buah tangan atau hadiah berupa buket snak ini dapat menjadi salah satu bentuk usaha bagi kalangan kawula muda khususnya bagi santri Miftahul Huda Alhusna. Salah satu pembelajaran yang diberikan kepada para santri tersebut adalah berniaga/berdagang, namun demikian ketatnya persaingan usaha menjadikan para santri tersebut harus mencoba berinovasi dalam membuat barang atau dagangan apa saja yang bisa dijadikan usaha dengan modal yang terjangkau dan kemajuan perkembangan teknologi menyebabkan para santri kesulitan dalam bersaing dipasaran sehingga masih banyak beberapa produk yang dijual tidak laku dikarenakan cara pengemasan dan pembuatan yang masih sederhana dan belum rapi. Maka dari itu melalui untuk membantu memecahkan permasalahan tersebut kami melakukan Iptek Bagi Masyarakat khususnya santri Miftahul Huda Alhusna bekerja sama dengan dn.stuff selaku salah satu pengrajin buket snack dan PT. Reliance Sekuritas Indonesia, Tbk. Selaku sponsorship pengadaan bahan-bahan pelatihan kewirausahaan bagi santri Miftahul Huda Alhusna.

Pesantren Miftahul Huda Alhusna merupakan salah satu pesantren yang terletak di Kelurahan Sukarindik Kecamatan Bungursari Kota Tasikmalaya dengan jumlah santri sebanyak 12 orang. Kebanyakan dari santri disana belajar berwirausaha dengan mendagangkan makanan ringan dan olahan rumahan lainnya.

Fenomena yang terjadi selama ini adalah para santri cenderung langsung 
menjual dagangannya kepada santri lainnya atau masyarakat sekitar pesantren saja tanpa adanya inovasi dan pemasaran yang lebih luas. Berdasarkan uraian tersebut perlu adanya usaha untuk memberikan pengetahuan dan pelatihan kepada santri Miftahul Huda Alhusna Oleh karena itu kami melakukan pelatihan sebagai alternative usaha dengan mengikuti tren kawula muda yaitu pembuatan buket snack.

Dalam prosesnya kami menggandeng pemilik usaha dn.stuff untuk memberikan ilmunya sekaligus sebagai mentor dalam cara-cara pembuatan buket snack dengan dibantu oleh PT. Reliance Sekuritas Indonesia, Tbk sebagai salah satu bentuk CSR perusahaan dengan menjadi sponsorship penyedia bahan-bahan yang diperlukan dalam pelatihan ini.

Dalam pelatihan kewirausahaan ini kami memanfaatkan limbah kertas sebagai salah satu bahan dalam pembuatan buket bunga bagi para santri Miftahul Huda Alhusna ini. Kertas-kertas yang sudah tidak terpakai seperti kertas bekas kalender, bekas karton yang tidak terpakai ataupun sudah terpakai, kertas bekas dus, dan kertas-kertas bekas lainnya yang kondisinya bersih dan dapat dijadikan alas penyangga bagi pembuatan buket bunga tersebut.

\section{METODE PELAKSANAAN}

Program pengabdian pada masyarakat dengan tema "Pelatihan Kewirausahaan dengan membuat buket snack sebagai alternative buah tangan bagi santri Miftahul Huda Alhusna Kecamatan Bungursari Kota Tasikmalaya" dilaksanakan dengan menggunakan :

\section{Metode Seminar}

Seminar merupakan pertemuan ilmiah yang dengan sistematis mempelajari suatu topik khusus dibawah pimpinan seorang ahli dan berwenang dalam bidang tersebut. Inti dari sebuah seminar merupakan sebuah diskusi, laporan seminar pun merupakan laporan hasil diskusi. Adapun keirausahaan menurut Amin (2008) merupakan sikap mental dan 
jiwa yang selalu aktif atau kreatif berdaya, bercipta, berkarsa dan bersahaja dalam berusaha dalam rangka meningkatkan pendapatan dalam kegiatan usahanya.

Sedangkan seminar mengenai produk bertujuan untuk memberikan kemampuan dalam mendesain bentuk dan model produk yang praktis untuk dikonsumsi. Dalam seminar pembuatan buket snack ini diharapkan para santri dapat berinovasi dalam berbagai aneka bentuk dan variasi buket snack sehingga dapat mempunyai nilai jual yang lebih baik dan dapat bersaing dengan produk yang lainnya.

Menurut Buchari Alma (2014:33) dalam bukunya Kewirausahaan untuk Mahasiswa dan Umum, Kewirausahaan adalah proses dinamik untuk menciptakan tambahan kemakmuran. Tambahan kemakmuran ini diciptakan oleh individu wirausaha yang menanggung resiko, menghabiskan waktu dan menyediakan berbagai produk barang dan jasa.

\section{Metode Pelatihan}

Pelatihan menurut Veithzal (2010) adalah proses secara sistematis mengubah tingkah laku pelaku usaha untuk mencapai tujuan yang berkaitan dengan keahlian dan kemampuan. Pelatihan yang kami berikan dengan mendatangkan salah satu pelaku usaha buket snack sebagai tutor atau pembimbing pembuatan buket snack.

Menurut Mathis (2002), Pelatihan adalah suatu proses dimana orang-orang mencapai kemampuan tertentu untuk membantu mencapai tujuan organisasi. Oleh karena itu, proses ini terikat dengan berbagai tujuan organisasi, pelatihan dapat dipandang secara sempit maupun luas.

Prosedur kerja yang dilaksanakan pertama kali adalah mengadakan survey lokasi kegiatan kemudian melakukan seminar kewirausahaan oleh dosen kewirausahaan dan pemasaran Fakultas Ekonomi Universitas Siliwangi serta seminar pembuatan buket snack oleh pelaku usaha buket snack dn.stuff kemudian baru dilakusanakan pelatihan 
pembuatan buket snack selama 6 jam Alur kegiatan pengabdian pada bertempat di Pesantren Miftahul Huda masyarakat ini digambarkan dalam Alhusna yang diikuti oleh 12 orang santri. gambar 1 berikut ini :

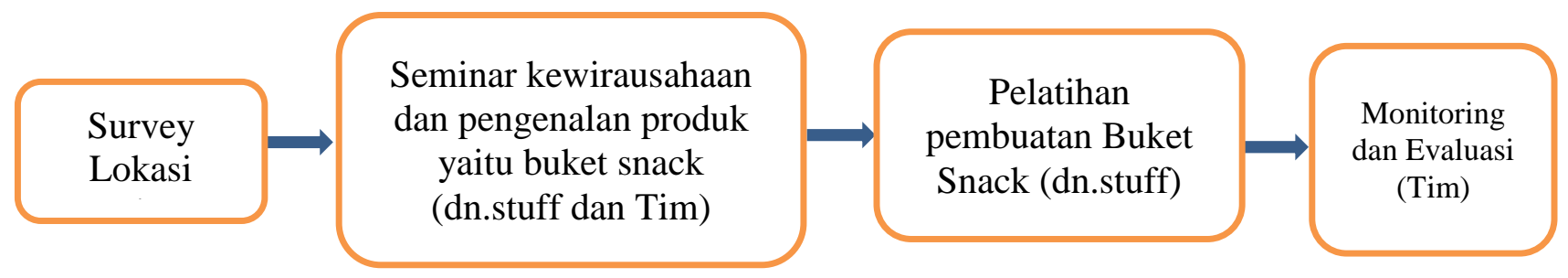

\section{Gambar 1. Alur Kegiatan}

Kegiatan ini juga didukung oleh partisipasi mitra dari Fakultas Ekonomi Universitas Siliwangi dan juga mitra dari dn.stuff yaitu PT. Reliance Sekutritas Indonesia, Tbk. Sebagai sponsorship kegiatan pengabdian pada masyarakat berupa penyedia bahan baku pelatihan buket snack pada santri Miftahul Huda Alhusna.

\section{HASIL DAN PEMBAHASAN}

Kegiatan pengabdian pada masyarakat berupa pelatihan kewirausahaan kepada santri Miftahul Huda Alhusna dengan membuat buket snack ini telah dilaksanakan pada $10-11$ Agustus 2019 melalui metode seminar dan pelatihan dengan hasil cukup baik. Hal ini bisa dilihat dari antusias para santri dan beberapa buket snack yang telah dihasilkan oleh para santri. Berikut adalah salah satu contoh buket snack yang dihasilkan terdapat dalam gambar 2

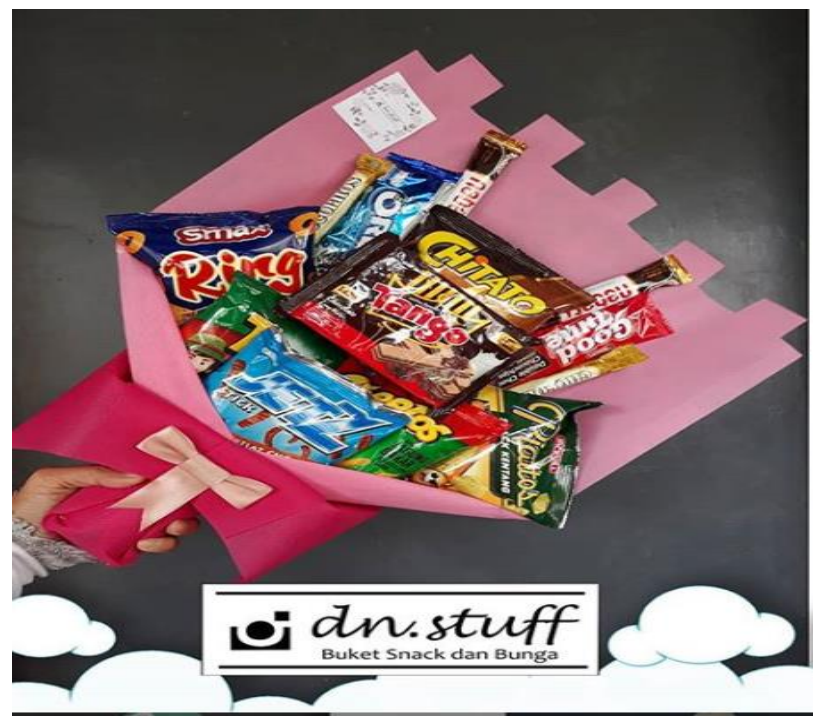

Gambar 2. Buket Snack 
Kegiatan ini dimulai dengan survey lokasi ke pesantren Miftahul Huda snack. Alhusna Kecamatan Bungursari Kota Tasikmalaya, kemudian dilakukan seminar kewirausahaan dan seminar pembuatan buket snack serta pemasaran buket. Seminar Kewirausahaan dan pemasaran ini dilaksanakan oleh dosen pemasaran Fakultas Ekonomi Universitas Siliwangi, sementara seminar pembuatan buket dilaksanakan oleh pelaku usaha buket snack dn.stuff dan tim PPM. Setelah survey dan seminar dilaksanakan baru dilakukan pelatihan pembuatan buket

Pelatihan pembuatan buket snack ini dengan memanfaatkan bahan dasar yang dapat dijangkau oleh para peserta pelatihan, diantaranya dengan memanfaatkan limbah kertas bekas sebagai bahan dasar pembuatan buket snack selain snack yang akan dijadikan buket tentunya. Berikut alur pelatihan pembuatan buket snack terdapat dalam gambar 3.

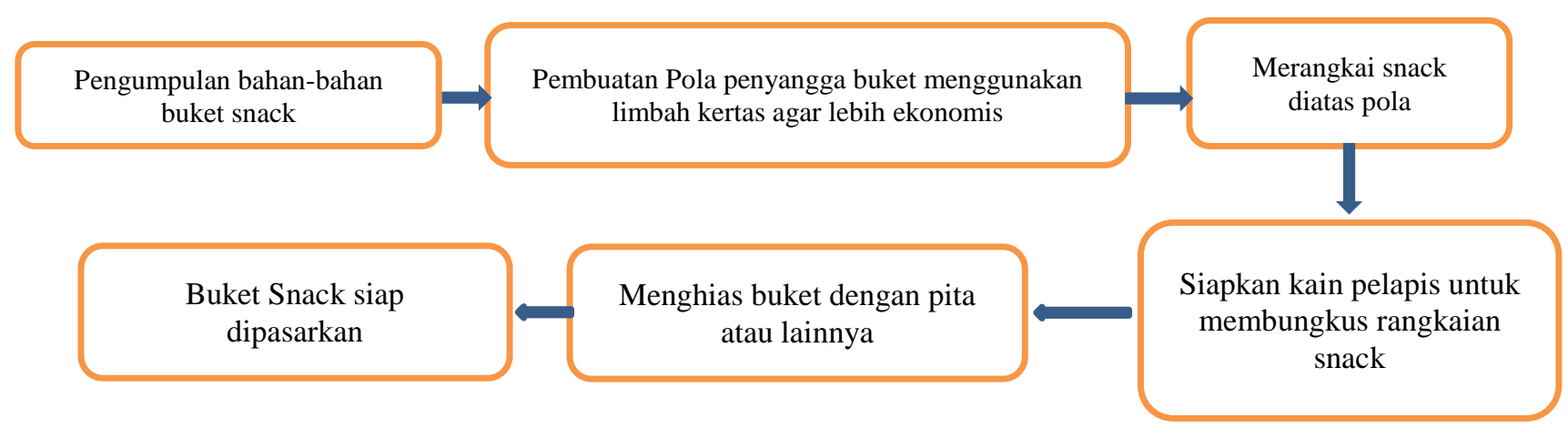

\section{Gambar 3. Alur Pelatihan Pembuatan Buket Snack}

Untuk langkah-langkah pembuatan buket snack bisa dilihat dalam gambar 4 berikut ini: 


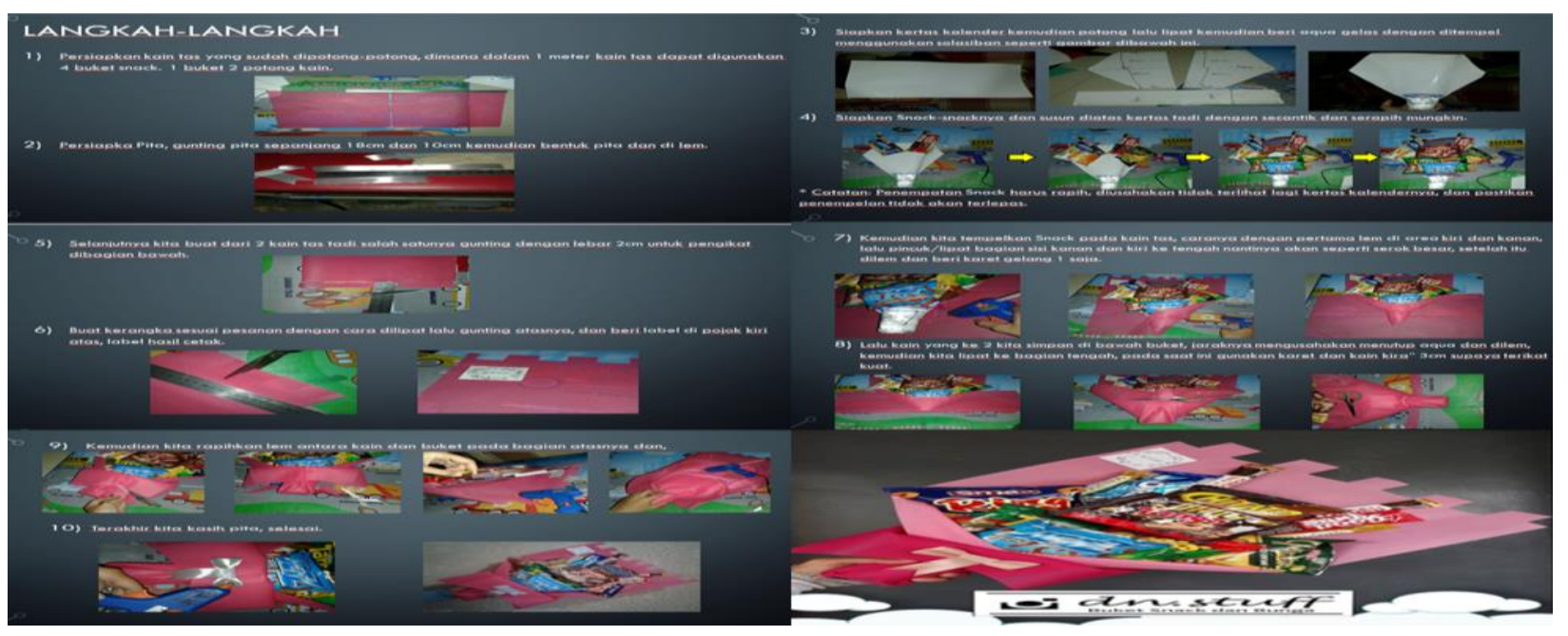

Gambar 4. Langkah-langkah pembuatan buket snack

Biaya yang diperlukan untuk bahan analisa usaha produksi buket snack pada dasar pembuatan buket snack sangatlah pelatihan kewirausahaan santri Miftahul terjangkau table 1 berikut menjelaskan Huda Alhusna sebagai berikut :

A. Aktiva Tetap

\begin{tabular}{|l|c|c|c|c|c|}
\hline Keterangan & Unit & Rp/Unit & Nilai & $\begin{array}{c}\text { Umur } \\
\text { Ekonomis }\end{array}$ & Penyusutan \\
\hline Lem & 1 & 50.000 & 40.000 & 2 & 66 \\
Tembak & 1 & 10.000 & 10.000 & 2 & 14 \\
Gunting & 1 & 10.000 & 10.000 & 2 & 14 \\
\hline \multicolumn{5}{|r}{ Nilai Penyusutan per 1 kali Proses Produksi } \\
\hline
\end{tabular}

\section{B. Biaya Variabel}

\begin{tabular}{|l|c|c|c|}
\hline \multicolumn{1}{|c|}{ Keterangan } & Unit & Rp/Unit & Nilai \\
\hline Lem Tembak & 12 & 442 & 884 \\
Solasiban & - & - & 400 \\
Karet Gelang & 12 & 200 & 2.400 \\
Kresek & 12 & 900 & 10.800 \\
Kertas & 12 & 2.000 & 24.000 \\
Pita & 12 & 1.000 & 12.000 \\
Aqua & 12 & 500 & 6.000 \\
Snack paket & 12 & - & 145.000 \\
Lain-lain & & & 10.000 \\
\hline \multicolumn{3}{|r|}{} \\
\hline
\end{tabular}




\section{Total Cost}

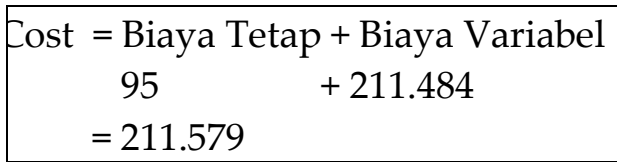

\section{Revenue}

ue dengan harga jual Rp.25.000 / buket adalah Rp. 300.000

untuk setiap buket yang terjual para santri (12 orang santri) mendapat keuntungan sebesar Rp. 7.368 / buket

Pada tabel diatas menjelaskan analisa usaha produksi buket snack pada pelatihan kewirausahaan santri Miftahul Huda Alhusna Kecamatan Bungursari Kota Tasikmalaya. Pada dasarnya buket snack dapat dijual dengan variasi harga yang berbeda-beda tergantung jenis isi snack yang dipakai dalam pembuatan buket snack, analisa tersebut dihitung dalam satu kali produksi yaitu 12 buket snack dalam satu hari dengan harga penjualan Rp.25.000.

Pemasaran buket snack ini dapat dipasarkan secara langsung kepada konsumen, melalui event-event tertentu seperti jadwal wisuda, jadwal siding, dan lain sebagainya. Selain itu, pemasaran buket snack ini dapat dilaksanakan melalui media online ataupun melalui pameran dengan pemasangan both penjualan.

Selanjutnya proses monitoring dan evaluasi dilakukan pada saat kegiatan HUT
Kemerdekaan RI ke 74 dengan mengikutsertakan peserta bazar oleh para santri pada bazar kemerdekaan di wilayah Liung gunung kelurahan Sukarindik Kota Tasikmalaya. Pada dasarnya para santri sudah dapat membuat dan mempunyai kreasi sendiri dalam pembuatan buket snack serta dapat memasarkan hasil dari pembuatan buket snack tersebut. Ini terlihat dari hampir habisnya buket snack dalam penjualan pada bazar tersebut. yang artinya pelatihan kewirausahaan dengan membuat buket snack sebagai alternative buah tangan pada santri Miftahul Huda Alhusna ini berhasil. Namun demikian kualitas dari buket snack masih harus lebih inovatif lagi dan masih belum rapi. Begitu juga dengan pemasarannya, para santri harus dapat memperluas jaringan pemasaran tidak hanya dipasarkan dilingkungan sekitar saja. 


\section{PENUTUP}

\section{KESIMPULAN}

Dari pelaksanaan kegiatan pelatihan kewirausahaan dalam rangka pengabdian pada masyarakat pada para santri Miftahul Huda Alhusna Kecamatan Bungursari Kota Tasikmalaya dengan pelatihan pembuatan buket snack ini dapat disimpulkan bahwa :

1. Tingkat kemahiran dan kerapihan santri berbeda-beda dalam pengemasan buket masih belum rapi jadi perlu dievaluasi lagi sehingga hasilnya dapat mempunyai daya saing.

2. Para santri mempunyai motivasi tinggi ketika diberikan motivasi kewirausahaan sehingga kegiatan ini sangatlah bermanfaat dan menarik.

3. Perlu diadakan pelatihan berkelanjutan di pesantren Miftahul Huda Alhusna agar para santri lebih mahir dan berinovasi dalam merangkai dan membentuk polapola yang baru dalam pembuatan buket snack tersebut sehingga usahnya dapat berlanjut tidak berhenti hanya sebatas pada saat pelatihan saja.

4. Mulai mahirnya para santri dalam pembuatan buket snack ini dapat dijadikan sebagai usaha lain dalam berwirausaha di Pesantren Miftahul Huda Alhusna.

5. Beberapa santri bahkan mempunyai motivasi tersendiri untuk mengembangkan bakatnya dan mengasah kemampuan dalam berinovasi bentuk buket dengan menjadi karyawan dn.stuff serta untuk mengumpulkan modal usaha dimana nantinya sudah bisa belajar mandiri berwirausaha. 


\section{REFERENSI}

Amin Widjaja Tunggal. (2008). Pengantar Kewirausahaan Edisi Revisi. Jakarta : Harvarindo

Buchari Alma. 2014. Kewirausahaan untuk Mahasiswa dan Umum. Bandung : Alfabeta

Mathis R.L dan Jackson J.H. 2002. Manajemen Sumber Daya Manusia. Jakarta : Salemba Empat

Rinandiyana, L.R. et al. (2016). Strategi Untuk Menciptakan Keunggulan Bersaing Melalui Pengembangan,
Desain, Produk (Kasus Pada Industri Pakaian Muslim Di Kota Tasikmalaya. Jurnal Manajemen 2. (2). $105-113$.

Veithzal Rivai. (2010). Manajemen Sumber Daya Manusia Untuk Perusahaan. Cetakan ke-3. Jakarta : PT. Raja Grafindo Persada.

https://youtu.be/ecD6Ww9HNbw 